\title{
Hepatitis B vaccination coverage in patients with diabetes mellitus
}

\author{
Cobertura vacinal contra hepatite $B$ em pacientes com diabetes mellitus \\ Cobertura vacunal contra hepatitis B en pacientes con diabetes mellitus
}

Clarissa Cordeiro Alves Arrelias' ${ }^{1}$, Fernando Bellissimo-Rodrigues ${ }^{2}$, Letícia Cristina Lourenço de Lima ${ }^{1}$, Anderson Soares da Silva ${ }^{2}$, Nereida Kilza da Costa Lima ${ }^{2}$, Maria Lucia Zanetti ${ }^{1}$

How to cite this article:

Arrelias CCA, Bellissimo-Rodrigues F, Lima LCL, Silva AS, Lima NKC, Zanetti ML. Hepatitis B vaccination coverage in patients with diabetes mellitus. Rev Esc Enferm USP. 2016;50(2):253-260. DOI: http://dx.doi.org/10.1590/S0080-623420160000200011

${ }^{1}$ Universidade de São Paulo, Escola de Enfermagem de Ribeirão Preto, Ribeirão Preto, SP, Brazil.

${ }^{2}$ Universidade de São Paulo, Faculdade de Medicina de Ribeirão Preto, Ribeirão Preto, SP, Brazil.

\begin{abstract}
Objective: Analyze the factors associated with full hepatitis B vaccination (three doses) in patients with diabetes mellitus. Method: Cross-sectional study, conducted in a health unit in a city in the state of São Paulo, with 255 patients on outpatient follow-up, in 2014. Data were obtained from the computerized system of the Municipal Health Department and via a structured questionnaire. A logistic regression model was used for analysis. Results: Full hepatitis B vaccination was noted in $13.7 \%$ of the patients and shown to be directly associated with their educational level $(\mathrm{OR}=1.30 ; \mathrm{CI}$ : $1.07-1.57)$ and current or previous work as a health professional $(\mathrm{OR}=3.21$; $\mathrm{CI}$ : 1.16-8.89). Conclusion: Hepatitis $\mathrm{B}$ vaccination coverage was found to be low in patients with diabetes mellitus, indicating their vulnerability to this serious and potentially fatal disease. Higher educational level and working in the field of health were associated with better vaccination coverage.
\end{abstract}

DESCRIPTORS

Hepatitis B; Immunization Coverage; Diabetes Mellitus; Educational Status; Health Personnel.
Corresponding author:

Clarissa Cordeiro Alves Arrelias

Escola de Enfermagem de Ribeirão Preto,

Universidade de São Paulo

Avenida Bandeirantes, 3900

Campus Universitário

CEP 14040-902 - Ribeirão Preto, SP, Brazil

claarrelias@usp.br
Received: 10/17/2015

Approved: 09/04/2016 


\section{INTRODUCTION}

Patients with diabetes mellitus (DM) constitute a recognized risk group for hepatitis $\mathrm{B}$ and $\mathrm{C}$ due to the invasive procedures needed to treat and control their disease. These procedures can lead to situations where syringes, needles and blood glucose monitoring devices are shared $^{(1-3)}$. The literature describes various outbreaks of hepatitis B in DM patients ${ }^{(3-5)}$.

In 2011, the Advisory Committee on Immunization Practices of the Centers for Disease Control and Prevention (CDC) in the United States, recommended, based on evidence, hepatitis $\mathrm{B}$ vaccination for DM patients from ages 19 to 59 , once a diagnosis is made, and for those aged 60 and older, after assessment of the risk and likelihood of an adequate immune response to vaccination ${ }^{(6)}$.

Hepatitis B vaccination has gradually been implemented in Brazil by the National Immunization Program of the Ministry of Health, since 1989, in some regions and for groups considered to be at risk of infection. In 1996, the vaccine started being distributed throughout Brazil for children under age one. Its extension to the population under age 20 occurred in 2001 and, in 2011, for the 20-24 age range. In January 2012, it included those up to age 29 , and in 2013 , up to age $49^{(7-8)}$. In 2016, free provision of the hepatitis $B$ vaccine was expanded to cover the entire population regardless of age or vulnerability ${ }^{(9)}$. Traditional immunization against the hepatitis $B$ virus (HBV) entails three doses of the vaccine via intramuscular injection, with a minimum interval of one month between the first and second dose, and six months between the first and third dose ${ }^{(10)}$.

The Brazilian Immunization Society recommends that DM patients be immunized with the hepatitis $B$ vaccine $^{(11)}$. However, in the National Immunization Program of the Ministry of Health, DM patients are still not recognized as being a vulnerable group, and there is no specific recommendation for vaccination against the disease. It is worth noting that the hepatitis $B$ vaccine is effective in preventing the infection and is recommended for DM patients regardless of the type of diabetes. The immune response to the vaccine in younger patients is similar to those with or without DM. However, for DM patients over age 40 , the immune response is lower in relation to those without $\mathrm{DM}^{(2,6)}$.

In the international literature, there are few studies on vaccination coverage for DM patients. Studies conducted in the USA show that hepatitis B vaccination coverage in the DM population is still low as compared to individuals without the disease $\mathrm{e}^{(12-14)}$.

In the national literature, there are studies on hepatitis B vaccination coverage for other populations, such as nursing babies, people under age 25 , health professionals, illicit drug users, sex workers and health students ${ }^{(15-23)}$. However, there is a shortage of knowledge regarding recommended hepatitis $B$ vaccination coverage for the population with DM.

Considering that DM patients represent a population with higher risk of contracting hepatitis $\mathrm{B}$, the objective of this study was to examine the factors associated with full hepatitis B vaccination (three doses) in DM patients receiving outpatient follow-up in a city in the state of São Paulo.

\section{METHOD}

A quantitative, observational, cross-sectional study was conducted from July to December 2014, in a District Basic Health Unit, in a city in the state of São Paulo. The target population consisted of $741 \mathrm{DM}$ patients, both men and women, 18 years of age or over, receiving follow-up in secondary care outpatient units (Integrated Outpatient Clinic or Endocrinology Outpatient Clinic) in the aforementioned health unit.

Patients who had hearing and cognitive ability to answer the questions in the data collection instrument and who freely consented to participate in the study were included. Of the 741 potential candidates, 419 were in active follow-up and had a medical appointment scheduled in the period from July to December 2014. Of these, 122 missed their appointments, 35 refused to participate in the study and seven were excluded due to some level of cognitive impairment. The convenience sample consisted of $255 \mathrm{DM}$ patients who showed up for their medical appointment in the Integrated Outpatient Clinic or Endocrinology Outpatient Clinic, from July to December 2014, and met the inclusion criteria, representing 60.9\% of the population of DM patients in active follow-up, in 2014 , in the aforementioned study location.

A questionnaire was used for data collection, containing demographic variables (gender, age and education); clinical variables (length of time with DM, insulin use, blood glucose monitoring, hepatitis $\mathrm{B}$ vaccination recommendation), and those related to vaccination coverage (number of hepatitis $B$ vaccine doses registered and those reported by the patient). The data related to the demographic, clinical and reported vaccination coverage variables were collected through interviews with patients, and the data corresponding to the number of doses, by consulting the vaccination records from the computerized Health Management System (Hygia Web), implemented in the city in 1994 and which interconnects all the units in the health care network. The system allows professionals to register each dose given. The doses given before the system's implementation can be registered through presentation of the patient's vaccination card. Patients with a hepatitis $B$ vaccination recommendation were defined as those who reported a job activity, such as a health professional, police officer, corrections officer, jailer, residential or hospital trash collector, manicurist, pedicurist or podiatrist and/or people with risk behaviors. Risk behavior was defined as current or past sexual or domestic contact with individuals with hepatitis $\mathrm{B}$, who smoked, inhaled or injected drugs, with a history of sexually communicable diseases and blood or blood product transfusions. Patients with records of at least three hepatitis $B$ vaccine doses were considered to have received full vaccination coverage.

Data were collected by two researchers previously trained on how to approach patients and apply the 
instrument. The researchers were in immersion for 12 days. This period was necessary to acquire knowledge about the care dynamics, available infrastructure and health professionals in the outpatient clinics. The activities were carried out in two stages.

Stage 1: DM patients were recruited through scheduled medical appointments. Every week the researcher checked the agenda for names of potential patients to be part of the study sample. With the list of potential patients in hand, on the scheduled day of the medical appointment, the researcher confirmed through the health records those diagnosed with DM. At the end of medical visit, the researcher introduced himself to the patient and presented the objectives and nature of the research. Those who agreed to participate were asked to sign two copies of a free and informed consent form - one for the researcher and the other for the patient. Data were collected by the researcher in a reserved room from Monday to Friday, during the afternoon in the Integrated Outpatient Clinic, and Tuesdays and Thursdays, during the morning and afternoon in the Endocrinology Outpatient Clinic. Average interview time was 15 minutes. The answers were transcribed in the instrument itself.

Second stage: access to the Hygia Web system to obtain data regarding the number of hepatitis $B$ vaccine doses received by DM patients. The data were recorded in the data collection instrument. The computers in the health unit were used.

For statistical analysis of the data, STATA 11.0 (Statacorp LP, College Station, United States) was used. Data were described by means of descriptive statistics and presented in absolute numbers and percentages. Univariate analysis of possible associations among the variables - demographic, clinical and full hepatitis B vaccination (three doses) - was determined by the Chisquare test with Pearson's correction, Fisher's exact test (bicaudal) and the Wilcoxon-Mann-Whitney test. For multivariate analysis of possible associations among selected variables - demographic (gender, age, education and profession), clinical (length of time diagnosed with DM, insulin use and blood glucose monitoring) and full hepatitis $B$ vaccination endpoint (three doses) - a logistic regression model was built. The variables included in the model were those which manifested a possible association with the endpoint variable in the univariate analysis $(p \leq 0.20)$. Independent variables were included in the model in an ordered way according to the significance level ( $p$-value) obtained in the univariate analysis. $\mathrm{P}$-values lower than $5 \%$ were considered significant for all analyses $(\alpha=0.05)$.

The research project was approved by the Research Ethics Committee of the Ribeirão Preto College of Nursing at the Universidade de São Paulo. Protocol: 24638213.2.0000.5393.

\section{RESULTS}

The characterization of the patients studied is found in Table 1.
Table 1 - Numerical and percentage distribution of DM patients according to demographic, clinical and hepatitis B vaccination coverage variables - Ribeirão Preto, São Paulo, Brazil, 2014.

\begin{tabular}{|c|c|c|}
\hline Variables & $\mathbf{n}$ & $\%$ \\
\hline \multicolumn{3}{|l|}{ Gender } \\
\hline Male & 85 & 33.3 \\
\hline Female & 170 & 66.7 \\
\hline \multicolumn{3}{|l|}{ Age } \\
\hline$\leq 49$ years & 35 & 13.8 \\
\hline$>49$ years & 220 & 86.2 \\
\hline \multicolumn{3}{|l|}{ Education } \\
\hline None & 9 & 3.5 \\
\hline Adult literacy & 2 & 0.8 \\
\hline $1^{\text {st }}-4^{\text {th }}$ Incomplete elementary education & 51 & 20.0 \\
\hline $1^{\text {st }}-4^{\text {th }}$ Complete elementary education & 69 & 27.1 \\
\hline $5^{\text {th }}-8^{\text {th }}$ Incomplete secondary education & 26 & 10.2 \\
\hline $5^{\text {th }}-8^{\text {th }}$ Complete secondary education & 31 & 12.2 \\
\hline Incomplete high school & 8 & 3.1 \\
\hline Complete high school & 39 & 15.3 \\
\hline Incomplete higher education & 10 & 3.9 \\
\hline Complete higher education & 10 & 3.9 \\
\hline \multicolumn{3}{|l|}{ Length of time with diabetes (years) } \\
\hline$<1$ & 9 & 3.5 \\
\hline $1-10$ & 129 & 50.6 \\
\hline $11-20$ & 71 & 27.8 \\
\hline $21-30$ & 35 & 13.7 \\
\hline $31-40$ & 10 & 3.9 \\
\hline $51-60$ & 1 & 0.4 \\
\hline \multicolumn{3}{|l|}{ Insulin use } \\
\hline Yes & 150 & 58.8 \\
\hline No & 105 & 41.2 \\
\hline \multicolumn{3}{|l|}{ Blood glucose monitoring } \\
\hline Yes & 190 & 74.5 \\
\hline No & 65 & 25.5 \\
\hline \multicolumn{3}{|l|}{ Health professional } \\
\hline Yes & 25 & 9.8 \\
\hline No & 230 & 90.2 \\
\hline \multicolumn{3}{|l|}{ Police officer/corrections officer/jailer } \\
\hline Yes & 5 & 1.6 \\
\hline No & 250 & 98.4 \\
\hline \multicolumn{3}{|l|}{ Residential/hospital trash collection worker } \\
\hline Yes & 8 & 3.1 \\
\hline No & 247 & 96.9 \\
\hline \multicolumn{3}{|l|}{ Manicurist/pedicurist/podiatrist } \\
\hline Yes & 12 & 4.7 \\
\hline No & 243 & 95.3 \\
\hline \multicolumn{3}{|l|}{ Risk behaviora } \\
\hline Yes & 197 & 77.3 \\
\hline No & 58 & 22.7 \\
\hline
\end{tabular}


Table 2 presents the number of hepatitis $B$ vaccine doses reported by DM patients and the number according to the records in the computerized system of the unit. Full

hepatitis B vaccination was observed in $13.7 \%$; for $4.7 \%$ it was incomplete; and $81.6 \%$ did not have any vaccinations registered.

Table 2 - Number of registered hepatitis B vaccine doses according to the number of doses reported by the patient - Ribeirão Preto, São Paulo, Brazil, 2014.

\begin{tabular}{|c|c|c|c|c|c|c|c|c|}
\hline \multirow{3}{*}{ Reported doses } & \multicolumn{8}{|c|}{ Registered doses } \\
\hline & \multicolumn{2}{|c|}{ No record } & \multicolumn{2}{|c|}{$\begin{array}{c}1 \text { or } 2 \\
\text { (incomplete) }\end{array}$} & \multicolumn{2}{|c|}{$\begin{array}{c}\geq 3 \\
\text { (complete) }\end{array}$} & \multicolumn{2}{|c|}{ Total } \\
\hline & $\mathbf{n}$ & $\%$ & $\mathbf{n}$ & $\%$ & $\mathbf{n}$ & $\%$ & $\mathbf{n}$ & $\%$ \\
\hline None & 80 & 96.4 & 1 & 1.2 & 2 & 2.4 & 83 & 100 \\
\hline 1 or 2 & 1 & 10.0 & 5 & 50.0 & 4 & 40.0 & 10 & 100 \\
\hline$\geq 3$ & 10 & 31.3 & 2 & 6.2 & 20 & 62.5 & 32 & 100 \\
\hline Does not know number of doses & 20 & 69.0 & 2 & 6.9 & 7 & 24.1 & 29 & 100 \\
\hline Does know if was vaccinated & 97 & 96.0 & 0 & 0.0 & 4 & 4.0 & 101 & 100 \\
\hline Total & 208 & 81.6 & 12 & 4.7 & 35 & 13.7 & 255 & 100 \\
\hline
\end{tabular}

Table 3 shows that the age median was lower among patients with full hepatitis $B$ vaccination compared to the others (60 and 64 years, respectively, $p=0.003$ ). Full vaccination was associated with completion of university $(p<0.001)$ and current or previous work as a health professional $(\mathrm{p}=0.001)$.

No significant association was found between full hepatitis $B$ vaccination and gender, length of time with DM, insulin use, blood glucose monitoring, other job activities investigated and risk behaviors (Table 3).

Table 3 - Hepatitis B vaccination coverage according to demographic and clinical variables examined - Ribeirão Preto, São Paulo, Brazil, 2014.

\begin{tabular}{|c|c|c|c|c|c|c|}
\hline \multirow{3}{*}{ Variables } & \multicolumn{6}{|c|}{ Registered doses } \\
\hline & \multicolumn{2}{|c|}{$<3^{a}$} & \multicolumn{2}{|c|}{$\geq 3$} & \multirow{2}{*}{$\mathbf{p}^{\mathbf{b}}$} & \multirow{2}{*}{ OR (Cl 95\%) } \\
\hline & $\mathbf{n}$ & $\%$ & $\mathbf{n}$ & $\%$ & & \\
\hline \multicolumn{7}{|l|}{ Gender } \\
\hline Male & 74 & 87.1 & 11 & 12.9 & & 1.00 \\
\hline Female & 146 & 85.9 & 24 & 14.1 & 0.797 & $1.10(0.51-2.38)$ \\
\hline \multicolumn{7}{|l|}{ Age } \\
\hline Median (p25-p75) & & $57-71)$ & & 7-65) & 0.003 & - \\
\hline$\leq 49$ years & 23 & 65.7 & 12 & 34.3 & & \\
\hline$>49$ years & 197 & 89.5 & 23 & 10.5 & & \\
\hline \multicolumn{7}{|l|}{ Education } \\
\hline None & 9 & 100.0 & 0 & 0.0 & & \\
\hline Adult literacy & 1 & 50.0 & 1 & 50.0 & & \\
\hline $1^{\text {st }}-4^{\text {th }}$ Incomplete elementary & 47 & 92.2 & 4 & 7.8 & & \\
\hline $1^{\text {st }}-4^{\text {th }}$ Complete elementary & 64 & 92.8 & 5 & 7.2 & & \\
\hline $5^{\text {th }}-8^{\text {th }}$ Incomplete secondary & 24 & 92.3 & 2 & 7.7 & & \\
\hline $5^{\text {th }}-8^{\text {th }}$ Complete secondary & 28 & 90.3 & 3 & 9.7 & & \\
\hline Incomplete high school & 5 & 62.5 & 3 & 37.5 & & \\
\hline Complete high school & 28 & 71.8 & 11 & 28.2 & & \\
\hline Incomplete higher education & 8 & 80.0 & 2 & 20.0 & & \\
\hline Complete higher education & 6 & 60.0 & 4 & 40.0 & $<0.001$ & - \\
\hline \multicolumn{7}{|l|}{ Length of time with diabetes } \\
\hline$<1$ & 7 & 77.8 & 2 & 22.2 & & \\
\hline $1-10$ & 113 & 87.6 & 16 & 12.4 & & \\
\hline $11-20$ & 59 & 83.1 & 12 & 16.9 & & \\
\hline $21-30$ & 30 & 85.7 & 5 & 14.3 & & \\
\hline
\end{tabular}


Registered doses

\begin{tabular}{|c|c|c|c|c|c|c|}
\hline \multirow{3}{*}{ Variables } & \multirow{2}{*}{\multicolumn{2}{|c|}{$<3^{a}$}} & \multirow{2}{*}{\multicolumn{2}{|c|}{$\geq 3$}} & \multirow{3}{*}{$\mathbf{p}^{\mathbf{b}}$} & \multirow{3}{*}{ OR (Cl 95\%) } \\
\hline & & & & & & \\
\hline & $\mathbf{n}$ & $\%$ & $\mathbf{n}$ & $\%$ & & \\
\hline $31-40$ & 10 & 100.0 & 0 & 0.0 & & \\
\hline $51-60$ & 1 & 100.0 & 0 & 0.0 & 0.865 & - \\
\hline \multicolumn{7}{|l|}{ Insulin use } \\
\hline No & 94 & 89.5 & 11 & 10.5 & & 1.00 \\
\hline Yes & 126 & 84.0 & 24 & 16.0 & 0.207 & $1.62(0.75-3.48)$ \\
\hline \multicolumn{7}{|c|}{ Blood glucose monitoring } \\
\hline No & 60 & 92.3 & 5 & 7.7 & & 1.00 \\
\hline Yes & 160 & 84.2 & 30 & 15.8 & 0.102 & $2.25(0.83-6.06)$ \\
\hline \multicolumn{7}{|c|}{ Health professional } \\
\hline No & 204 & 88.7 & 26 & 11.3 & & 1.00 \\
\hline Yes & 16 & 64.0 & 9 & 36.0 & 0.001 & $\begin{array}{c}4.41 \text { (1.77- } \\
10.99)\end{array}$ \\
\hline \multicolumn{7}{|c|}{ Police officer/corrections officer/jailer } \\
\hline No & 216 & 86.4 & 34 & 13.6 & & 1.00 \\
\hline Yes & 4 & 80.0 & 1 & 20.0 & 0.683 & $1.58(0.17-14.6)$ \\
\hline \multicolumn{7}{|c|}{ Residential/hospital trash collection worker } \\
\hline No & 212 & 85.8 & 35 & 14.2 & & \\
\hline Yes & 8 & 100.0 & 0 & 0.0 & 0.604 & - \\
\hline \multicolumn{7}{|c|}{ Manicurist/pedicurist/podiatrist } \\
\hline No & 210 & 86.4 & 33 & 13.6 & & 1.00 \\
\hline Yes & 10 & 83.3 & 2 & 16.7 & 0.762 & $1.27(0.26-6.06)$ \\
\hline \multicolumn{7}{|c|}{ Risk behaviorc } \\
\hline No & 170 & 86.3 & 27 & 13.7 & & 1.00 \\
\hline Yes & 50 & 86.2 & 8 & 13.8 & 0.986 & $1.00(0.43-2.35)$ \\
\hline
\end{tabular}

a Patients with one, two or no doses registered.

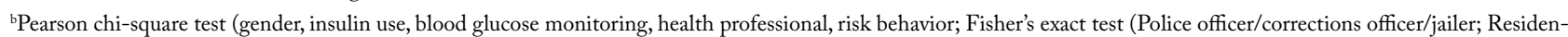
tial/hospital trash collection worker; Manicurist/pedicurist/podiatrist), Wilcoxon-Mann-Whitney test (Age, education, length of time with DM).

'Current or past sexual or domestic contact with individuals with hepatitis B, having smoked, inhaled or injected drugs, having a history of sexually communicable diseases and blood or blood product transfusions.

In the logistic regression analysis (Table 4), full hepatitis $B$ vaccination was directly associated with the patient's educational level $(\mathrm{OR}=1.26$; $\mathrm{CI}$ : 1.03-1.53) and current or previous work as a health professional $(\mathrm{OR}=3.21$; $\mathrm{CI}$ : 1.168.89), but not with age (OR=0.97; CI: 0.93-1.01), unlike the findings in the univariate analysis.

Table 4 - Logistic regression model for hepatitis B vaccination coverage ( $\geq 3$ doses) - Ribeirão Preto, São Paulo, Brazil, 2014.

\begin{tabular}{lccc}
\hline Variables & OR (CI 95\%) & p & Standard error \\
\hline Female & $1.45(0.61-3.41)$ & 0.391 & 0.63 \\
Age & $0.97(0.93-1.01)$ & 0.175 & 0.01 \\
Education & $1.26(1.03-1.53)$ & 0.020 & 0.12 \\
Length of time with DM & $0.99(0.94-1.04)$ & 0.809 & 0.02 \\
Insulin use & $11.1(0.38-3.21)$ & 0.846 & 0.60 \\
Blood glucose monitoring & $1.56(0.43-5.61)$ & 0.489 & 1.02 \\
Health professional & $3.21(1.16-8.89)$ & 0.024 & 1.66 \\
\hline
\end{tabular}

OR: odds ratio; each variable was adjusted to the other six. 


\section{DISCUSSION}

The proposed design for performing the study does not enable establishing cause and effect relationships between vaccination coverage and the variables examined. However, it is possible through the results to obtain the hepatitis $B$ vaccination diagnosis among DM patients.

The demographic and clinical characteristics of the sample studied are consistent with two cross-sectional studies with DM patients receiving outpatient care in the city that was investigated ${ }^{(24-25)}$.

Full vaccination found was $13.7 \%$, lower than in a retrospective study conducted with a non-institutionalized population in the USA, which showed that hepatitis B vaccination rates were $22.4 \%$ from 1999 to $2008^{(14)}$. However, another study conducted with a non-institutionalized DM population sample in the USA in $2009^{(12)}$ found that full hepatitis $B$ vaccination was $16.6 \%$, close to the results in this study. In relation to the incomplete vaccination scheme, the proportion of DM patients who had received one or two doses of the vaccine (19.5\%) was higher, when compared with this study (4.7\%). The proportion of DM patients with no vaccinations registered $(81.6 \%)$ was also higher in comparison to the study conducted in the USA, in $2009(63.9 \%)^{(12)}$.

Full hepatitis B vaccination has increased in the DM population. A study conducted with a non-institutionalized population sample in the USA, in 2015, found that full hepatitis $\mathrm{B}$ vaccination was $17.1 \%{ }^{(13)}$. These results show a slight increase in full vaccination in relation to the study conducted in 2009, and that adhesion to the hepatitis B vaccination recommendation for DM patients is still $\operatorname{low}^{(12-}$ ${ }^{13)}$. In this regard, future studies are needed to investigate the factors which interfere with achieving the hepatitis B vaccination goals for people with $\mathrm{DM}$.

It is important to emphasize that, in Brazil, the importance of hepatitis $B$ vaccinations for people with DM is not much disseminated, unlike the influenza vaccine, where DM is included as a risk category for influenza, and is recommended and available for people with DM. A population-based study conducted among older people in the city of Campinas, state of São Paulo, from 2008 to 2009, found an association between diabetes and annual influenza vaccination ${ }^{(26)}$.

In comparing the number of hepatitis B doses reported by DM patients and those registered in the Hygia Web System, of the patients who reported not having received any vaccine dose, $96.4 \%$ did not have any vaccination registered. This shows a high correlation between the information reported and the data registered. In relation to those who reported not knowing whether they had been vaccinated, $96 \%$ did not have any vaccination registered and among those who reported not knowing the number of doses received, $69 \%$ did not have anything registered in the system. Of the patients who reported an incomplete vaccination scheme, it was registered in one half of the cases, whereas for the full scheme, it was registered in $40 \%$ of the cases. These results may reflect the patients' lack of information regarding the importance of hepatitis B vaccination for DM patients, or difficulty remembering if they had received the hepatitis $B$ vaccination or not, as well as report the number of doses received. However, it cannot be presumed that information alone will modify attitudes toward protection against hepatitis B. In this regard, having health professionals monitor the vaccination calendar of DM patients could be an effective strategy in diabetes education.

Of the patients who reported a full vaccination scheme, it was also registered in $62.5 \%$ of the cases and in $31.3 \%$ it was not. Possible losses of records related to the time and place where the DM patient was vaccinated represents a challenge for health services to improve and expand health information systems, and is one of the priorities in nursing research ${ }^{(27)}$.

In examining the variables related to full vaccination, an association was found between younger ages and vaccination. Full vaccination was $34.3 \%$ among patients 49 years of age and less, as opposed to $10.5 \%$ for those over 49. However, the association between age and full hepatitis $B$ vaccination was not confirmed after the logistic regression analysis, concurring with a similar study conducted in the USA, in $2009^{(12)}$. In Brazil, during the period in which the study data were collected, hepatitis $B$ vaccination was recommended and available for the adult population up to age 49 , which could explain the greater prevalence of vaccination in patients aged 49 and under.

On the other hand, it was found that educational level is directly linked to hepatitis B coverage, which coincides with a similar study conducted in the USA, in 2009 ${ }^{(12)}$. The importance of information for DM patients about the hepatitis vaccination scheme is an effective and accessible way to prevent infection. Patients with lower educational levels, older ages and receiving DM follow-up need special attention due to the complexity of the treatment. The hepatitis vaccination scheme, since it is comprised of three doses, is difficult for patients to understand and follow, causing many to abandon the proposed vaccination scheme. In this regard, the hepatitis $B$ vaccination scheme needs to be reinforced with DM patients during their visits with health professionals, as well as be followed up until the vaccination scheme is completed. Therefore, it is recommended that hepatitis B vaccination be included in a list of information provided to DM patients, particularly those who use insulin, monitor blood glucose and are subject to other risk factors.

There was also an association between working as a health professional, whether currently or in the past, and full hepatitis vaccination, as found in a similar study conducted in the USA, in $2009^{(12)}$. Hepatitis B vaccination is recommended for health professionals and available in the public health system for any age range, which may explain these results ${ }^{(28-29)}$.

The results obtained serve as a starting point for future studies related to the importance of immunization for DM patients and training of nursing care professionals, since these represent a risk population for infection by the hepatitis $\mathrm{B}$ virus ${ }^{(1-3,30)}$.

A limitation of the study regards the data source (the computerized Health Management System), since, in the sample studied, DM patients vaccinated before 1994 or in other cities and who do not have a vaccination card may 
underestimate the recommendation for full hepatitis vaccination. However, these situations are not very likely, since the study sample is predominantly elderly and the availability of the vaccine for adults, recent.

\section{CONCLUSION}

Hepatitis B vaccination coverage was found to be low in DM patients, indicating their vulnerability to this serious and potentially fatal disease. Higher educational level and working in the health field were associated with better vaccination coverage. This data reveals the urgent need to include DM patients in the National Immunization Program as a priority group for hepatitis B vaccination. This study provides important input for evaluating the clinical practices of primary health care nurses in providing care related to vaccination coverage for people with diabetes mellitus.

\section{RESUMO}

Objetivo: Analisar os fatores associados à vacinação completa contra hepatite B (3 doses) em pacientes com diabetes mellitus. Método: Estudo transversal, realizado em uma Unidade de Saúde, de uma cidade do interior paulista, com 255 pacientes em seguimento ambulatorial, em 2014. Os dados foram obtidos no sistema informatizado da Secretaria Municipal de Saúde e por meio de um questionário estruturado e, para análise, modelo de regressão logística. Resultados: Vacinação completa contra hepatite B foi observada em $13,7 \%$ dos pacientes e mostrou-se diretamente associada ao nível de escolaridade (OR=1,30; IC: $1,07-1,57)$ e ao trabalho atual ou pregresso como profissional da saúde $(\mathrm{OR}=3,21$; IC: 1,16-8,89). Conclusão: A cobertura vacinal contra hepatite $\mathrm{B}$ mostrou-se baixa em pacientes com diabetes mellitus, evidenciando a vulnerabilidade a essa doença grave e potencialmente fatal. Maior escolaridade e o trabalho na área da saúde foram associados a melhor cobertura vacinal.

\section{DESCRITORES}

Hepatite B; Cobertura Vacinal; Diabetes Mellitus; Escolaridade; Pessoal de Saúde.

\section{RESUMEN}

Objetivo: Analizar los factores asociados con la vacunación completa contra hepatitis B ( 3 dosis) en pacientes con diabetes mellitus. Método: Estudios transversal, llevado a cabo en una Unidad de Salud de una ciudad del interior paulista, con 255 pacientes en seguimiento ambulatorio, en 2014. Los datos fueron obtenidos en el sistema informatizado de la Secretaría Municipal de Salud y mediante un cuestionario estructurado y, para el análisis, un modelo de regresión logística. Resultados: Vacunación completa contra hepatitis B fue observada en el 13,7\% de los pacientes y se mostró directamente asociada con el nivel de escolaridad (OR=1,30; IC: 1,07$1,57)$ y con el trabajo actual o anterior como profesional sanitario $(\mathrm{OR}=3,21 ; \mathrm{IC}: 1,16-8,89)$. Conclusión: La cobertura vacunal contra hepatitis $\mathrm{B}$ se mostró baja en pacientes con diabetes mellitus, evidenciándose la vulnerabilidad a esa enfermedad severa y potencialmente fatal. Mayor escolaridad y el trabajo en el área sanitaria estuvieron asociados con la mejor cobertura vacunal.

\section{DESCRIPTORES}

Hepatitis B; Cobertura de Vacunación; Diabetes Mellitus; Escolaridad; Personal de Salud.

\section{REFERENCES}

1. Reilly ML, Schillie SF, Smith E, Poissant T, Vonderwahl CW, Gerard K, et al. Increased risk of acute hepatitis B among adults with diagnosed diabetes mellitus. J Diabetes Sci Technol. 2012;6(4):858-66.

2. Schillie SF, Spradling PR, Murphy TV. Immune response of hepatitis B vaccine among persons with diabetes. Diabetes Care. 2012;35(12):2690-7.

3. Thompson ND, Perz JF, Moorman AC, Holmberg SD. Nonhospital health care associated hepatitis B and C virus transmission: United States, 1998-2008. Ann Intern Med. 2009;150(1):33-9.

4. Bender TJ, Wise ME, Utah O, Moorman AC, Sharapov U, Drobeniuc J, et al. Outbreak of Hepatitis B virus infections associated with assisted monitoring of blood glucose in an assisted living facility-Virginia, 2010. PLoS One. 2012;7(12):e50012.

5. Duffell EF, Milne LM, Seng C, Young Y, Xavier S, King S, et al. Five hepatitis B outbreaks in care homes in the UK associated with deficiencies in infection control practice in blood glucose monitoring. Epidemiol Infec. 2011;139(3):327-35.

6. Centers for Disease Control and Prevention. Use of hepatitis B vaccination for adults with diabetes mellitus: recommendations of the Advisory Committee on Immunization Practices (ACIP). MMWR Morb Mortal Wkly Rep. 2011;60(50):1709-11.

7. Brasil. Ministério da Saúde; Secretaria de Vigilância em Saúde, Departamento de Vigilância Epidemiológica. Programa Nacional de Imunizações (PNI): 40 anos [Internet]. Brasília: MS; 2013 [citado 2016 jan. 11]. Disponível em: http://bvsms.saude.gov.br/bvs/publicacoes/ programa_nacional_imunizacoes_pni40.pdf

8. Domingues CMAS, Teixeira AMS. Coberturas vacinais e doenças imunopreveníveis no Brasil no período 1982- 2012: avanços e desafios do Programa Nacional de Imunizações. Epidemiol Serv Saúde. 2013;22(1):9-27.

9. Brasil. Ministério da Saúde, Secretaria de Vigilância em Saúde, Departamento de Vigilância das Doenças Transmissíveis, Coordenação Geral do Programa Nacional de Imunizações. Nota Informativa n.149, de 2015. Informa as mudanças no Calendário Nacional de Vacinação para o ano de 2016 [Internet]. Brasília: MS; 2015 [citado 2016 jan. 11]. Disponível em: http://www.cvpvacinas.com.br/pdf/ nota_informativa_149.pdf

10. São Paulo (Estado). Secretaria de Estado da Saúde, Coordenadoria de Controle de Doenças, Centro de Vigilância Epidemiológica, Divisão de Imunização. Vacina contra hepatite B. Rev Saúde Pública. 2006;40(6):1137-40. 
11. Sociedade Brasileira de Imunizações (SBIM). Guia de Vacinação 2013/2014. Pacientes especiais. São Paulo: SBIM; 2013.

12. Byrd KK, Lu P, Murphy TV. Baseline hepatitis B vaccination coverage among persons with diabetes before implementing a U.S. recommendation for vaccination. Vaccine. 2012;30(23):3376-82.

13. Williams WW, Lu P, O'Halloran A, Bridges CB, Kim DK, Pilishvili T, et al. Vaccination coverage among adults, excluding influenza vaccination: United States, 2013. MMWR Morb Mortal Wkly Rep. 2015;64(4):95-102.

14. Younossi ZM, Stepanova M. Changes in hepatitis A e B vaccination rates in adults patients with chronic liver diseases and diabetes in the U.S. population. Hepatology. 2011;54(4):1167-78.

15. Queiroz LLC, Monteiro SG, Mochel EG, Veras MASM, Sousa FGM, Bezerra MLM, et al. Cobertura vacinal do esquema básico para o primeiro ano de vida nas capitais do Nordeste brasileiro. Cad Saúde Pública. 2013;29(2):294-302.

16. Bueno MM, Matijasevich A. Avaliação da cobertura vacinal contra hepatite B nos menores de 20 anos em municípios do Estado do Rio Grande do Sul, Brasil. Epidemiol Serv Saúde. 2011;20(3):345-54.

17. Riente KBC, Tsuguta EN, Barbosa SRBS, Zaparoli MA. Avaliação da cobertura vacinal contra hepatite B em 15 municípios da região metropolitana oeste de São Paulo. BECVE. 2012;2(10):162-73.

18. Francisco PMSB, Donalisio MR, Gabriel FJO, Barros MBA. Vacinação contra hepatite B em adolescentes residentes em Campinas, São Paulo, Brasil. Rev Bras Epidemiol. 2015;18(3):552-67.

19. Rossato EM, Ferreira J. Acidentes com perfurocortantes e cobertura vacinal contra hepatite B entre trabalhadores da Saúde no Município de Santa Rosa, Estado do Rio Grande do Sul, Brasil, 2008. Epidemiol Serv Saúde. 2012 ;2(3):487-96.

20. Assunção AÁ, Araújo TM, Ribeiro RBN, Oliveira SVS. Vacinação contra hepatite B e exposição ocupacional no setor saúde em Belo Horizonte, Minas Gerais. Rev Saúde Pública. 2012;46(4):665-73.

21. Attilio JS, Rodrigues FP, Renovato RD, Sales CM, Alvarenga MRM, Moreira MT, et al. Cobertura vacinal contra hepatite B entre usuários de drogas ilícitas. Acta Paul Enferm. 2011;24(1):101-6.

22. Carneiro LM, Mousquer GJ, Pinheiro RS, Castro AR, França DD, Caetano KA, et al. Outreach hepatitis B vaccination of female sex workers in central-west Brazil: immunization status, compliance, and immune response. J Public Health Manag Pract. 2014;20(6):662-6.

23. Souza EP, Teixeira MS. Hepatitis B vaccination coverage and postvaccination serologic testing among medical students at a public university in Brazil. Rev Inst Med Trop Sao Paulo. 2014;56(4):307-11.

24. Chagas IA, Camilo J, Santos MA, Rodrigues FFL, Arrelias CCA, Teixeira CRS. Patients' knowledge of diabetes five years after the end of an educational program. Rev Esc Enferm USP. 2013;47(5):1142-7.

25. Zulian LR, Santos MA, Veras VS, Rodrigues FFL, Arrelias CCA, Zanetti ML. Qualidade de vida de pacientes com diabetes utilizando o instrumento Diabetes 39 (D-39). Rev Gaúcha Enferm. 2013;34(3):138-46.

26. Francisco PMSB, Barros MBA, Cordeiro MRD. Vacinação contra influenza em idosos: prevalência, fatores associados e motivos da nãoadesão em Campinas, São Paulo, Brasil. Cad Saúde Pública. 2011;27(3):417-26.

27. Cassiani SHB, Bassalobre-Garcia A, Reveiz L. Acesso Universal à Saúde e Cobertura Universal de Saúde: identificação de prioridades de pesquisa em enfermagem na América Latina. Rev Latino Am Enfermagem. 2015;23(6):1195-208.

28. Centers for Disease Control and Prevention, Advisory Committee on Immunization Practices. Immunization of health-care personnel: recommendations of the Advisory Committee on Immunization Practices (ACIP). MMWR Recomm Rep. 2011;60(RR-7):1-45.

29. Bellissimo-Rodrigues WT, Machado AA, Bellissimo-Rodrigues F, Nascimento MP, Figueiredo JFC. Prevalence of hepatitis B and C among Brazilian dentists. Infect Control Hosp Epidemiol. 2006;27(8):887-8.

30. Teston EF, Torre e Silva RLD, Marcon SS. Living with hepatitis: impact on the daily life of infected subjects. Rev Esc Enferm. USP [Internet]. 2013 [cited 2016 Jan 11];47(4):860-8. Available from: http://www.scielo.br/pdf/reeusp/v47n4/en_0080-6234-reeusp-47-4-0860.pdf 